\title{
Extraction of Phenolic Compounds from Black Mulberry Using Aqueous, Ethanol and Aqueous-Ethanol Solvents: Effects of Heat Treatments on Chemical Properties of the Extracts
}

\author{
Samira Yazdankhah ${ }^{1}$, Mohammad Hojjati $^{2 *}$, Mohammad Hossein Azizi $^{3}$ \\ 1- Department of Food Science and Technology, Masjed Soleyman Branch, Islamic Azad University, Masjed Soleyman, Iran \\ 2- Department of Food Science and Technology, Khuzestan Agricultural Sciences and Natural Resources University, Ahwaz, Iran \\ 3- Department of Food Science and Technology, Faculty of Agriculture, Tarbiat Modares University, Tehran, Iran
}

Accepted: June 2019

\section{A B S T R A C T}

Background and Objectives: Black mulberry is a juicy and dark purple to black fruit with a good balance of sweetness and tartness. This fruit is highly interested due to high quantities of anthocyanins. The bioactive compounds are often present in fruit tissues and should be released. The aim of this study was to extract bioactive compounds of black mulberries and assessment of heating process effects on the extracted compounds.

Materials and Methods: Aqueous, ethanol and aqueous-ethanol solvents were used for the extraction processes. The physicochemical properties of extracts, including total phenol, total anthocyanin content, anthocyanin profile, antioxidant activity, acidity and total solids, were investigated. Then, the aqueous-ethanol extract was subjected to direct heating, microwave heating and non-thermal (gamma radiation) processes to assess their possible effects on the extract.

Results: The aqueous-ethanol extract included higher total phenol $(68.94 \mathrm{mg} \mathrm{GAE} / \mathrm{g})$ and anthocyanin contents (226.16 $\mathrm{mg} / \mathrm{ml}$ ), higher antioxidant activity (DPPH of $90.29 \%$ and FRAP of 1.42) as well as higher quantities of anthocyanins (cyanidin-3-glucoside, cyanidin-3-rutinoside and cyanidin-3-xyloside of 277.36, 53.21, and $11.44 \mathrm{mg} / \mathrm{ml}$, respectively). It was observed that less time and power of heating, microwave and gamma radiation conditions included less deteriorative effects on anthocyanin compounds and thus a higher antioxidant activity was seen.

Conclusions: Aqueous-ethanol solvents include further extraction efficiencies on phenolic compounds and anthocyanins and are considered as appropriate chemicals for the extraction of bioactive compounds from black mulberries. Furthermore, moderate heating conditions can preserve higher quantities of anthocyanins.

Keywords: Black mulberry, Aqueous-ethanol extraction, Anthocyanin, HPLC

\section{Introduction}

Consumption of colorful fruits such as berries has been increased recently because of their positive biological effects (1). Berries consumption includes beneficial health effects, including decreased cardiovascular diseases, lowered blood pressures, decreased insulin resistances and protected consumers against metabolic syndromes (1-3). Furthermore, radical scavenging activity (RSA) has been reported for the colorful fruits. Studies have demonstrated that free radicals, which cause cancer cell promotions, are neutralized and consequently cell metabolisms are regulated (1). The biological effects are mostly associated with the plant compounds. These compounds can potentially include antioxidant activities, which can be attributed to their reducing agents $(4,5)$. The bioactive compounds are mainly classified to phenolic and anthocyanin groups $(2,6)$. The two main groups can be found in plant tissues as insoluble complex structures; therefore, extraction processes should be carried out to achieve the bioactive compounds (e.g. anthocyanins and phenolic acids) at the highest rehabilitate capacity $(2,7)$. It is worth mentioning that the extraction conditions, including $\mathrm{pH}$, temperature and solvent type, can affect numbers of active rehabilitation points (7). Conventional extraction or maceration procedure, 
which is carried out through sets of temperature, time and solvent/material ratio, has been more studied due to its convenient handling and availability $(4,8)$. Nowadays, food technologists are interested in processing methods with less deteriorative effects on bioactive compounds (9,10). For example, microwave-based baking methods are used for processing polar food systems. Use of ultraviolet (UV) light and gamma ray for surface disinfection of pathogens is preferred to heat treatments due to radiation less deteriorative effects on nutraceutical compounds (10). Therefore, comparisons between heat treatment, microwave treatment and $\gamma$-ray radiation are further interesting. Since food enrichment with natural antioxidants is an beneficial issue; hence, presevation of the highlighted compounds during processing must be considered as an critical issue $(9,11)$.

Berries, as colorant fruits, contain high levels of phenolic compounds and anthocyanins such as cyanidin-based anthocyanins, tannins, chlorogenic acids and flavonoids $(12,13)$. Studies have reported cyanidins as prevailing anthocyanin compounds in three blackberry cultivars of Jumbo, Black Satin and Dirksen (13). Recently, the antidiabetic potential of black mulberry extract enriched pasta has been studied and shown that diabetes mellitus type 2 can be cured using polyphenolic compounds of black mulberries (14). These compounds can contribute to potent antioxidant activities and act as radical scavengers (12). Moreover, cardio protective effects have been verified for phenolic extracts from Chilean blackberries, namely Aristotelia chilensis (15). The aim of the current study was to extract bioactive compounds of black mulberry fruits containing phenolics and anthocyanins. Therefore, aqueous and ethanolic extraction protocols were used as maceration extraction procedures. Comparisons of heat, microwave and gamma-radiation treatment effects on bioactive compounds were other aims of the present study. Experiments were carried out to achieve a favorable processing method with less adverse effects on nutraceutical compounds.

\section{Materials and Methods}

Materials: Fresh black mulberry fruits were purchased from Mollasani Region of Southwestern Iran, April 2017. Fruits were cleaned from impurities to prevent spoilage. These were packaged in polyethylene bags and stored at $-18{ }^{\circ} \mathrm{C}$ until use. The analytical-grade chemicals such as ethanol, methanol, 2,2-diphenyl-1-picrylhydrazyl (DPPH), gallic acid, Folin-Ciocalteu reagent, ascorbic acid and phenolphthalein were purchased from Merck (Germany) and Sigma-Aldrich (USA).

Extraction of anthocyanins: Maceration method was used to extract phenolic and anthocyanin compounds. First, black mulberry fruits were ground and then mixed with the solvents at a ratio of 1:10. Two solvents in three extraction forms of water (aqueous extraction), ethanol and a mixture of both at 50:50 ratios were used for extraction. Mixtures were agitated at $200 \mathrm{rpm}$ at constant ambient temperature and stored for $3 \mathrm{~h}$ to be more efficiently extracted. Then, mixtures were filtered through Whatman papers No. 1 using Buchner funnels. Residual of black mulberry pulps were collected and re-extracted using fresh solvents with similar conditions. All chemical analyses were carried out on fresh and freeze-dried extracts.

Chemical properties of the black mulberry extracts: Moisture, ash, protein, total dietary fiber (TDF) contents and acidity of samples were assessed using standard AOAC methods nos. 920.151, 940.26, 920.152, 985.29 and 942.15, respectively (16). The $\mathrm{pH}$ and total solid content (TSC) contents of the extracts were calculated using Titrino 654 laboratory $\mathrm{pH}$ meter (Metrohm, Switzerland) and Karl Zeiss 32F refractometer (Jena, Germany), respectively.

Total phenol content (TPC): The TPC of black mulberry extracts was calculated based on a method described by Ozgen et al. (17) with minor modifications. Briefly, $300 \mu \mathrm{L}$ of the prepared extracts were poured into experimental glass tubes and mixed with $1.5 \mathrm{ml}$ of Folin-Ciocalteu reagent water-diluted solution (1:10). This was set on bench for $10 \mathrm{~min}$ at room temperature to react. Then, $2 \mathrm{ml}$ of sodium carbonate $(7.5 \% \mathrm{w} / \mathrm{v})$ were added into the solution and mixed well. Tubes were stored for 120 min at room temperature to complete the process. Absorbance of the solutions was then measured using spectrophotometer at $765 \mathrm{~nm}$. The TPC was expressed as $\mathrm{mg}$ gallic acid equivalent per $\mathrm{g}$ of the extract powder.

Antioxidant activity: Antioxidant activity of the extracts was assessed using DPPH and ferric reducing antioxidant power (FRAP) assays based on original methods by Lou et al. (6) and Ozgen et al. (17) with 
some modifications, respectively. The $\mathrm{IC}_{50}$ values were expressed for the extracts to show the least effective concentrations that scavenge $50 \%$ of the $\mathrm{DPPH}$ free radicals. The $\mathrm{IC}_{50}$ was calculated from the plot of inhibition percentage against sample concentration.

Total anthocyanin content (TAC): The TAC of the extracts was calculated based on the $\mathrm{pH}$ differences of black mulberry extracts (18). Potassium chloride buffer ( $\mathrm{pH} 1.0,0.025 \mathrm{M})$ and sodium acetate $(\mathrm{pH} 4.5$, $0.4 \mathrm{M}$ ) were used for preparing two extract solutions. Dilution was carried out at a ratio of 9:1. Absorbance of the solutions was measured using spectrophotometer at 510 and $700 \mathrm{~nm}$ and distilled water used as blank. The $\mathrm{pH}$ differential was calculated by substituting the two absorbance values at two certain points of $\mathrm{pH}$ based on the following equation:

$\mathrm{A}=\left(\mathrm{A}_{510}-\mathrm{A}_{700}\right)_{\mathrm{pH} 1.0}-\left(\mathrm{A}_{510}-\mathrm{A}_{700}\right)_{\mathrm{pH} 4.5}$

Where, $\mathrm{A}$ was $\mathrm{pH}$ differential value associated to black mulberry extract dilutions in buffer systems.

The A value was used to quantify samples TAC based on the following equation:

Total anthocyanins content $\left(\frac{\mathrm{mg}}{\mathrm{L}}\right)=\frac{\mathrm{A} \times \mathrm{MW} \times \mathrm{DF} \times 10^{3}}{\varepsilon \times 1}$

The TAC was expressed base on mg of cyanidin-3glucoside equivalent per liter where MW (molecular weight $)=449.2 \mathrm{~g} / \mathrm{mol}$ for cyanidin-3-glucoside $($ cyd 3-glu); DF = dilution factor of black mulberry extract; $1=$ path length in $\mathrm{cm} ; \varepsilon=26,900 \mathrm{M}$ extinction coefficient in $L \times \mathrm{mol}^{-1} \times \mathrm{cm}^{-1}$ for cyd-3-glu and $10^{3}$ $=$ factor for conversion from $\mathrm{g}$ to $\mathrm{mg}$.

Quantification of anthocyanins using highperformance liquid chromatography (HPLC): Anthocyanins of the black mulberry extracts were identified using HPLC according to Chen et al. (19) and Benmeziane et al. (20) methods with partial modifications. First, mulberry extracts were centrifuged and filtered using Millipore filters with a cutoff of $20 \mathrm{kDa}$ (Microcon YM-10, Millipore, Bedford, USA). A $10-\mu \mathrm{L}$ of the extracts was injected into Azura HPLC system (Knauer, Berlin, Germany) consisting of a binary pump (LC, P $6.1 \mathrm{~L}$ ) equipped with UV-Vis photodiode-array detector (DAD 2.1 L, Knauer), 5- $\mu \mathrm{m}$ ODS3 reversed-phase prodigy column $(250 \times 4.6 \mathrm{~mm}$; Phenomenex, Torrance, CA, USA $)$ and eluted solvent A (water:formic acid 90:10) and solvent B (formic acid:acetonitrile 10:90) at $1 \mathrm{ml} / \mathrm{min}$ under the gradient condition at $20{ }^{\circ} \mathrm{C}$. The analysis was carried out based on the comparison of associated retention times of peaks with those of pure standards. Cyanidin-3-glucoside,

cyanidin-3-rutinoside, cyanidin-3-xyloside, delphinidin-3-glucoside and pelargonidin-3-glucose were used as standards. The Chromgate Software (Knauer, Berlin, Germany) was used to analyze data. All analyses were carried out in duplicate.

Heat treatments of the black mulberry extracts: Thermal and non-thermal treatments were used to investigate respective effects on phytochemical compounds of the black mulberry extracts. The extracts were selected based on the antioxidant activity and highest phenolic and anthocyanin contents. Thermal heat treatments were set on four various conditions of $70{ }^{\circ} \mathrm{C}(30$ and $45 \mathrm{~s})$ and $85{ }^{\circ} \mathrm{C}$ (30 and $45 \mathrm{~s}$ ). Non-thermal treatments included use of microwave and $\gamma$-radiation. Microwave treatment was carried out at 600 and $900 \mathrm{~W}$ for 30 and $45 \mathrm{~s}$. The $\gamma$ radiation was carried out at three various beam powers of 5, 7.5 and $10 \mathrm{KG}$.

Statistical analysis: All analyses were reported as means \pm SD (standard deviation). The SPSS Software v.19 (SPSS Inc., Chicago, IL, USA) and analysis of variance (ANOVA) were used to investigate significant differences between the average values (95\% confidence). Significant differences between the means were calculated using Duncan test at a significant level of $P<0.05$.

\section{Results}

Chemical properties of the black mulberry extracts: Chemical properties of the fresh black mulberry fruits are shown in Table 1. Results of chemical attributes for the black mulberry extracts from three various solvents are presented in Table 2. The minimum and maximum $\mathrm{pH}$ values were measured as 4.56 and 5.39 for ethanol and aqueous extracts, respectively. The $\mathrm{pH}$ value was reported as 5.39 for aqueous-ethanol extract. The highest and lowest acidity values were reported for the samples extracted with ethanolic (1.81\%) and aqueous (1.52\%) solvents, respectively. For TSC, aqueousethanol extract presented the highest $(10.16 \%)$ and aqueous extract presented the lowest (9.12\%) quantities of TSC. As shown in Table 2, TSC in ethanol extract was $9.72 \%$ which is significantly higher than that in aqueous extract but lower than that in aqueous ethanol $(P<0.05)$. 
Samira Yazdankhah, et al: Effect of heat treatments on chemical properties of black mulberry extract

Table 1. Chemical properties of the fresh black mulberry fruits

\begin{tabular}{|c|c|c|c|c|c|c|c|c|c|}
\hline Sample & $\begin{array}{c}\text { Moisture } \\
(\%)\end{array}$ & $\begin{array}{c}\text { Total } \\
\text { solid }(\%)\end{array}$ & $\begin{array}{l}\text { Reducing } \\
\text { sugars }(\%)\end{array}$ & $\begin{array}{c}\text { Total } \\
\text { sugar }(\%)\end{array}$ & $\begin{array}{l}\text { Ash } \\
(\%)\end{array}$ & $\begin{array}{c}\text { Dietary } \\
\text { fiber }(\%)\end{array}$ & $\begin{array}{c}\text { Protein } \\
(\%)\end{array}$ & $\mathrm{pH}$ & $\begin{array}{l}\text { Acidity } \\
\text { (malic } \\
\text { acid\%) }\end{array}$ \\
\hline $\begin{array}{l}\text { Black mulberry } \\
\text { fruits }\end{array}$ & 88.11 & 11 & 4.83 & 5.3 & 0.78 & 1.37 & 2.1 & 4.03 & 0.64 \\
\hline
\end{tabular}

Table 2. Chemical properties of the black mulberry extracts using aqueous, ethanol and aqueous-ethanol extractions

\begin{tabular}{|c|c|c|c|c|c|c|c|c|}
\hline Sample & $\mathrm{pH}$ & $\begin{array}{c}\text { Acidity } \\
(\text { malic acid } \%)\end{array}$ & $\begin{array}{c}\text { Total solid } \\
(\%)\end{array}$ & $\begin{array}{c}\text { Total phenol } \\
\text { content }\end{array}$ & $\begin{array}{c}\text { Total anthocyanin } \\
\text { content }\end{array}$ & DPPH $\%$ & $\begin{array}{c}\text { FRAP } \\
(\mathrm{mg} \mathrm{TE} / \mathrm{g} \mathrm{db})\end{array}$ & $\mathrm{IC}_{50}(\mathrm{mg} / \mathrm{ml})$ \\
\hline Aqueous extract & $5.39 \pm 0.026^{\mathrm{a}}$ & $1.52 \pm 0.01^{\mathrm{c}}$ & $9.12 \pm 0.071^{\mathrm{c}}$ & $58.77 \pm 0.67^{c}$ & $200.29 \pm 1.49^{c}$ & $74.22 \pm 1.119^{\mathrm{c}}$ & $1.17 \pm 0.01^{\mathrm{c}}$ & $1840 \pm 95.8^{\mathrm{c}}$ \\
\hline Ethanol extract & $4.56 \pm 0.02^{\mathrm{c}}$ & $1.81 \pm 0.016^{\mathrm{a}}$ & $9.72 \pm 0.061^{\mathrm{b}}$ & $65.76 \pm 1.036^{\mathrm{b}}$ & $209.68 \pm 2.53^{\mathrm{b}}$ & $79.38 \pm 1.429^{b}$ & $1.28 \pm 0.005^{\mathrm{b}}$ & $450 \pm 13.50^{\mathrm{b}}$ \\
\hline $\begin{array}{l}\text { Aqueous/ethanol } \\
\text { extract }\end{array}$ & $4.77 \pm 0.01^{\mathrm{b}}$ & $1.75 \pm 0.01^{b}$ & $10.16 \pm 0.176^{\mathrm{a}}$ & $68.94 \pm 0.861^{\mathrm{a}}$ & $226.16 \pm 3.36^{\mathrm{a}}$ & $90.29 \pm 0.157^{\mathrm{a}}$ & $1.42 \pm 0.01^{\mathrm{a}}$ & $288 \pm 12.70^{\mathrm{a}}$ \\
\hline
\end{tabular}

Different letters in each column indicate significant differences $(P<0.05)$

Total phenol content (TPC): The ethanol-water extract included a higher TPC value $(68.94 \mathrm{mg}$ GAE/g), compared to those other extracts did (58.77 and $65.76 \mathrm{mg} \mathrm{GAE} / \mathrm{g}$ for aqueous and ethanol extracts, respectively) (Table 2). The aqueous-ethanol significantly included a higher TPC value than that the ethanol extract did $(P<0.05)$. As seen in Table 2, the aqueous-ethanol extract significantly included a higher TAC $(226.16 \mathrm{mg} / \mathrm{L})$, compared to that aqueous $(200.29 \mathrm{mg} / \mathrm{L})$ or ethanol $(209.68 \mathrm{mg} / \mathrm{L})$ extract did. Ethanol extracted a little anthocyanins relatively.

Antioxidant activity: The antioxidant activity was calculated as $90.29 \%$ for aqueous-ethanol extract, which can be related to higher phenolic and anthocyanin contents (Table 2). The aqueous extract (74.22\%) showed the least antioxidant activity with DPPH assay. The FRAP results were provided in Table. Similar results were measured for FRAP since aqueous-ethanol extract revealed higher FRAP amount (1.42) which had a significant difference with the values belonged to aqueous or ethanol extracts $(P$ $<0.05)$. Another antioxidant index for black mulberry extracts was $\mathrm{IC}_{50}$ values that defining as the least amount (concentration) of antioxidant substances that could reduce $50 \%$ of free DPPH radicals. Therefore, the lower concentration of antioxidant, the stronger antioxidant activity could be implied. Lower $\mathrm{IC}_{50}$ value $(288 \mu \mathrm{g} / \mathrm{ml})$ obtained for aqueous-ethanol which could be due to its higher phenolic and anthocyanin contents. Conversely, just aqueous extract indicated higher $\mathrm{IC}_{50}(1840 \mu \mathrm{g} / \mathrm{ml})$ due to lower phenolic compounds that was extracted in water media.

Quantification of anthocyanins using highperformance liquid chromatography (HPLC): Results from the quantification of various black mulberry extracts with HPLC are shown in Figure 1. These results showed that cyanidin-3-glucoside was the major anthocyanidin compound in all samples and cyanidin-3-rutinoside and cyanidin-3-xyloside were the major anthocyanin compounds, respectively. The HPLC analysis of samples revealed that the highest and lowest amount of cyanidin-3-glucoside was found in aqueous/ethanol $(277.36 \mathrm{mg} / \mathrm{ml})$ and aqueous $(179.75 \mathrm{mg} / \mathrm{ml})$ extracts, respectively. Results showed the highest and the lowest quantities of cyanidin-3rutinoside in ethanol $(58.91 \mathrm{mg} / \mathrm{L})$ and aqueous $(17.65 \mathrm{mg} / \mathrm{L})$ extracts, respectively. In contrast, cyanidin-3-xyloside was not detected in the aqueous extract. The quantity of cyanidin-3-xyloside in ethanol extract $(14.41 \mathrm{mg} / \mathrm{L})$ was higher than that in aqueous-ethanol extract $(11.44 \mathrm{mg} / \mathrm{L})$. 


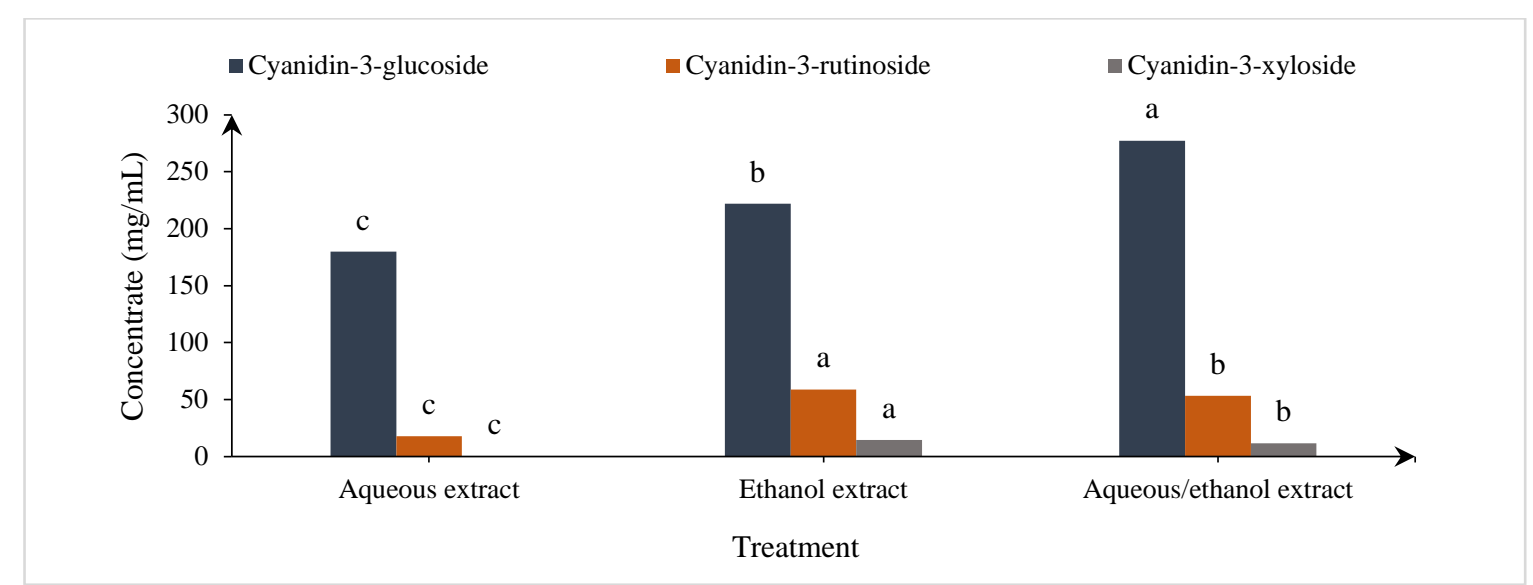

Figure 1. Anthocyanin compound analysis of various black mulberry extracts using high-performance liquid chromatography (HPLC). Different letters in each column indicate significant differences $(P<0.05)$

\section{Heat treatment effects on chemical properties of} the aqueous-ethanol extracts: In general, chemical properties of the aqueous-ethanol extract were affected by thermal (direct heat), non-thermal (microwave) and $\gamma$-radiation treatments (Table 3). The crude TPC was calculated as $68.94 \mathrm{GAE} / \mathrm{g}$ dry wt. for the aqueous ethanol extract that was significantly higher than treated samples. Microwave treatment demonstrated lower changes (decrease) in TPC, compared to that other treatments did. The highest decrease belonged to microwave treatment with process conditions of $900 \mathrm{~W}$ for $45 \mathrm{~s}$ and $\gamma$ radiation with beam powers of 7.5 and $10 \mathrm{KG}$. The TAC changes are shown in Table 3. The TAC was reported as $226.13 \mathrm{mg} / \mathrm{ml}$ using crude extracts. Instead, the lowest quantity of TAC $(196.62 \mathrm{mg} / \mathrm{ml})$ was achieved in samples heated at $85{ }^{\circ} \mathrm{C}$ for $45 \mathrm{~s}$. Moreover, microwave treatment at $600 \mathrm{~W}$ for $30 \mathrm{~s}$ caused the lowest changes. The $\gamma$-radiation showed a relatively higher TAC $(210.11 \mathrm{mg} / \mathrm{ml})$ only at $5 \mathrm{KG}$. The RSA values of crude samples subjected to thermal and non-thermal treatments are presented in Table 3. Crude extracts showed the highest DPPH RSA (90.29\%) while samples exposed to microwaves at $900 \mathrm{~W}$ for $45 \mathrm{~s}$ showed the lowest DPPH RSA. Similar results were achieved for thermal treatments with less deteriorative effects. The $\gamma$-radiation treatments showed a lower antioxidant activity (79.82\%), especially at the highest power $(10 \mathrm{KG})$, compared to that other treatments did. Results of the FRAP antioxidant activity were similar to those described previously. The highest FRAP values (1.42) were achieved for the crude samples while the lowest values were achieved for the samples of microwave treatments at $900 \mathrm{~W}$ for $45 \mathrm{~s}$. Partial decreases were observed for samples exposed to $70{ }^{\circ} \mathrm{C}$ for $30 \mathrm{~s}$ and subjected to $\gamma$-radiation at $5 \mathrm{KG}$. For $\mathrm{IC}_{50}$, the lowest value $(288 \mu \mathrm{g} / \mathrm{ml})$ was reported for the crude samples. The highest value of $\mathrm{IC}_{50}(1133 \mu \mathrm{g} / \mathrm{ml})$ was reported for the samples exposed to $\gamma$-radiation at $10 \mathrm{KG}$. Acidity values of the samples ranged 1.61-1.76 with no significant differences $(P<0.05)$.

Heat treatment effects on anthocyanin contents of the aqueous-ethanol extracts: Anthocyanin contents were assessed after exposing the aqueous-ethanol black mulberry extracts to thermal and non-thermal treatments (Table 4). Results showed significant differences in moisture cyanidin-3-glucoside contents of the samples due to the thermal treatments $(P<0.05)$; hence, all heat treatments decreased cyanidin-3-glucoside contents in aqueous-ethanol black mulberry extracts. The crude extracts included highest quantity of cyanidin-3-glucoside (277.36 $\mathrm{mg} / \mathrm{ml}$ ) whereas samples exposed to direct heat at 85 ${ }^{\circ} \mathrm{C}$ for $45 \mathrm{~s}$ included the lowest quantity (187.54 $\mathrm{mg} / \mathrm{ml})$. Using microwaves, the moderate exposure power $(600 \mathrm{~W}$ for $30 \mathrm{~s})$ included lower adverse effects on cyanidin-3-glucoside contents (264.95 $\mathrm{mg} / \mathrm{ml}$ ), while a higher exposure power and longer time $(900 \mathrm{~W}$ for $45 \mathrm{~s}$ ) decreased cyanidin-3-glucoside to $189.69 \mathrm{mg} / \mathrm{ml}$. Furthermore, $\gamma$-radiation decreased cyanidin-3-glucoside contents to $194.9 \mathrm{mg} / \mathrm{ml}$, especially at higher power $(10 \mathrm{KG})$. Similar results were seen for cyanidin-3-rutinoside and cyanidin-3xyloside contents and their values decreased due to the thermal and non-thermal heat treatments. Since the moderate condition of thermal or non-thermal treatment included less deteriorative effects on bioactive compounds, further anthocyanins were achieved. 
Samira Yazdankhah, et al: Effect of heat treatments on chemical properties of black mulberry extract

Table 3. Effects of thermal and non-thermal heats on chemical characteristics of the aqueous-ethanol black mulberry extracts

\begin{tabular}{|c|c|c|c|c|c|c|}
\hline Treatment/sample & $\begin{array}{l}\mathrm{DPPH} \\
(\%)\end{array}$ & $\begin{array}{c}\text { FRAP } \\
(\mathrm{mg} \mathrm{TE} / \mathrm{g} \mathrm{db})\end{array}$ & $\mathrm{IC}_{50}(\mu \mathrm{g} / \mathrm{ml})$ & $\begin{array}{l}\text { Total phenol } \\
\text { content }\end{array}$ & $\begin{array}{l}\text { Anthocyanin content } \\
(\mathrm{mg} / \mathrm{ml})\end{array}$ & $\begin{array}{c}\text { Acidity } \\
\text { (malic } \\
\text { acid\%) }\end{array}$ \\
\hline $\begin{array}{l}\text { aqueous/ethanol extract } \\
\text { (plain sample) }\end{array}$ & $90.29 \pm 0.15^{\mathrm{a}}$ & $1.42 \pm 0.01^{\mathrm{a}}$ & $288 \pm 12.70^{i}$ & $68.94 \pm 0.86^{\mathrm{a}}$ & $226.16 \pm 3.36^{\mathrm{a}}$ & $1.75 \pm 0.01^{\mathrm{a}}$ \\
\hline $\begin{array}{l}\text { direct heat treatment } \\
\left(70^{\circ} \mathrm{C}-30 \mathrm{~s}\right)\end{array}$ & $87.15 \pm 0.22^{\mathrm{bc}}$ & $1.38 \pm 0.00^{\mathrm{b}}$ & $331 \pm 8.00^{\mathrm{h}}$ & $67.61 \pm 0.32^{\mathrm{b}}$ & $210.68 \pm 0.99^{\mathrm{bc}}$ & $1.61 \pm 0.03^{\mathrm{ab}}$ \\
\hline $\begin{array}{l}\text { direct heat treatment } \\
\left(70^{\circ} \mathrm{C}-45 \mathrm{~s}\right)\end{array}$ & $86.36 \pm 0.02^{\mathrm{c}}$ & $1.25 \pm 0.00^{\mathrm{e}}$ & $340 \pm 8.90^{\mathrm{h}}$ & $65.99 \pm 0.67^{\mathrm{bc}}$ & $200.75 \pm 1.00^{\mathrm{fg}}$ & $1.62 \pm 0.05^{\mathrm{ab}}$ \\
\hline $\begin{array}{l}\text { direct heat treatment } \\
\left(85^{\circ} \mathrm{C}-30 \mathrm{~s}\right)\end{array}$ & $86.05 \pm 0.34^{\mathrm{cd}}$ & $1.24 \pm 0.00^{\mathrm{e}}$ & $415 \pm 12.10^{\mathrm{g}}$ & $65.78 \pm 0.96^{\mathrm{bc}}$ & $202.33 \pm 1.84^{\mathrm{ef}}$ & $1.73 \pm 0.01^{\mathrm{a}}$ \\
\hline $\begin{array}{l}\text { direct heat treatment } \\
\left(85^{\circ} \mathrm{C}-45 \mathrm{~s}\right)\end{array}$ & $83.81 \pm 0.17^{\text {ef }}$ & $1.17 \pm 0.00^{\mathrm{f}}$ & $454 \pm 3.60^{\mathrm{ef}}$ & $63.14 \pm 0.34^{\mathrm{e}}$ & $196.62 \pm 0.73^{\mathrm{g}}$ & $1.68 \pm 0.02^{\mathrm{a}}$ \\
\hline $\begin{array}{l}\text { microwave treatment } \\
(600 \mathrm{~W}, 30 \mathrm{~s})\end{array}$ & $89.11 \pm 0.11^{\mathrm{ab}}$ & $1.42 \pm 0.00^{\mathrm{a}}$ & $483 \pm 4.10^{\mathrm{de}}$ & $68.11 \pm 0.11^{\mathrm{a}}$ & $213.40 \pm 0.38^{b}$ & $1.72 \pm 0.12^{\mathrm{a}}$ \\
\hline $\begin{array}{l}\text { microwave treatment } \\
(600 \mathrm{~W}, 45 \mathrm{~s})\end{array}$ & $81.98 \pm 1.31^{\mathrm{fg}}$ & $1.34 \pm 0.01^{\mathrm{c}}$ & $535 \pm 13.70^{c}$ & $65.51 \pm 0.65^{\mathrm{cd}}$ & $206.45 \pm 0.52^{\text {cde }}$ & $1.65 \pm 0.01^{\mathrm{ab}}$ \\
\hline $\begin{array}{l}\text { microwave treatment } \\
(900 \mathrm{~W}, 30 \mathrm{~s})\end{array}$ & $81.71 \pm 0.74^{\mathrm{gh}}$ & $1.34 \pm 0.00^{\mathrm{c}}$ & $515 \pm 6.20^{\mathrm{cd}}$ & $63.51 \pm 0.68^{\mathrm{de}}$ & $208.59 \pm 1.08^{\mathrm{cd}}$ & $1.64 \pm 0.02^{\mathrm{ab}}$ \\
\hline $\begin{array}{l}\text { microwave treatment } \\
(900 \mathrm{~W}, 45 \mathrm{~s})\end{array}$ & $76.51 \pm 0.79^{i}$ & $0.98 \pm 0.01^{\mathrm{g}}$ & $790 \pm 7.20^{\mathrm{b}}$ & $60.25 \pm 0.22^{f}$ & $200.54 \pm 0.61^{\mathrm{fg}}$ & $1.69 \pm 0.07^{\mathrm{a}}$ \\
\hline $\begin{array}{l}\text { gamma radiation } \\
(5 \mathrm{KG})\end{array}$ & $84.15 \pm 1.47^{\mathrm{de}}$ & $1.41 \pm 0.01^{\mathrm{ab}}$ & $431 \pm 15.80^{\mathrm{fg}}$ & $65.42 \pm 0.68^{\mathrm{cd}}$ & $210.11 \pm 1.18^{\mathrm{bc}}$ & $1.63 \pm 0.04^{\mathrm{ab}}$ \\
\hline $\begin{array}{l}\text { gamma radiation } \\
(7.5 \mathrm{KG})\end{array}$ & $81.36 \pm 0.49^{\mathrm{gh}}$ & $1.29 \pm 0.01^{\mathrm{d}}$ & $762 \pm 23.60^{\mathrm{b}}$ & $62.11 \pm 0.90^{\mathrm{ef}}$ & $206.26 \pm 0.89^{\text {cde }}$ & $1.66 \pm 0.00$ \\
\hline $\begin{array}{l}\text { gamma radiation } \\
(10 \mathrm{KG})\end{array}$ & $79.82 \pm 0.32^{\mathrm{h}}$ & $1.24 \pm 0.01^{\mathrm{e}}$ & $1133 \pm 12.20^{\mathrm{a}}$ & $60.61 \pm 0.67^{f}$ & $204.10 \pm 1.41^{\text {def }}$ & $1.76 \pm 0.05^{\mathrm{a}}$ \\
\hline
\end{tabular}

Different letters in each column indicate significant differences $(P<0.05)$

Table 4. Effects of thermal and non-thermal heats on anthocyanin compounds of the aqueous-ethanol black mulberry extracts

\begin{tabular}{lccc}
\hline Treatment/sample & $\begin{array}{c}\text { Cyanidin-3-glucoside } \\
(\mathrm{mg} / \mathrm{ml})\end{array}$ & $\begin{array}{c}\text { Cyanidin-3-rutinoside } \\
(\mathrm{mg} / \mathrm{ml})\end{array}$ & $\begin{array}{c}\text { Cyanidin-3-xyloside } \\
(\mathrm{mg} / \mathrm{ml})\end{array}$ \\
\hline aqueous/ethanol extract (plain sample) & 277.36 & 53.21 & 11.44 \\
direct heat treatment $\left(70^{\circ} \mathrm{C}-30 \mathrm{~s}\right)$ & 219.25 & 33.31 & 9.73 \\
direct heat treatment $\left(70^{\circ} \mathrm{C}-45 \mathrm{~s}\right)$ & 188.75 & 18.78 & 8.81 \\
direct heat treatment $\left(85^{\circ} \mathrm{C}-30 \mathrm{~s}\right)$ & 199.10 & 15.09 & 5.97 \\
direct heat treatment $\left(85^{\circ} \mathrm{C}-45 \mathrm{~s}\right)$ & 187.54 & 14.15 & 2.39 \\
microwave treatment $(600 \mathrm{~W}, 30 \mathrm{~s})$ & 264.95 & 35.49 & 8.43 \\
microwave treatment $(600 \mathrm{~W}, 45 \mathrm{~s})$ & 198.25 & 39.64 & 7.99 \\
microwave treatment $(900 \mathrm{~W}, 30 \mathrm{~s})$ & 200.03 & 33.31 & 5.31 \\
microwave treatment $(900 \mathrm{~W}, 45 \mathrm{~s})$ & 189.69 & 23.31 & 2.11 \\
gamma radiation $(5 \mathrm{KG})$ & 223.34 & 41.03 & 10.25 \\
gamma radiation $(7.5 \mathrm{KG})$ & 196.25 & 33.64 & 8.21 \\
gamma radiation $(10 \mathrm{KG})$ & 194.90 & 28.31 & 5.31 \\
\hline
\end{tabular}

Different letters in each column indicate significant differences $(P<0.05)$

\section{Discussion}

\section{Chemical properties of the black mulberry}

extracts: The aqueous-ethanol extract showed moderate values of $\mathrm{pH}$. It seems that addition of ethanol to water could support further organic acid extractions. Citric and malic acid have been reported as dominant acids in black mulberry fruits $(3,19)$. Ethanol shows less polar properties than water and malic acid with the respective chemical structure $\left(\mathrm{C}_{4} \mathrm{H}_{6} \mathrm{O}_{5}\right)$; therefore, acid compounds with lower polar characteristics could easily diffuse into ethanol-based media and the compounds could be extracted more easily and quickly. Furthermore, phenolic acids could be involved in $\mathrm{pH}$ decrease of fruit extracts (21). Therefore, aqueous media alone extract less phenolic acids due to the limited polar pathes in the system. In this study, it was observed that ethanol could increase extraction of solid materials. Semi-polar ingredients such as phenolic compounds can be removed from the plant tissues using organic solvents. Aqueous media mainly facilitate extraction of polar compounds while ethanol-based media facilitate extraction of semipolar or less-polar ingredients. These results are similar to results by Sarkar et al. (22). Use of mixed solvents can potentially increase solid material 
diffusion into the extraction media $(18,13)$. Therefore, this can be used to achieve higher solid material diffusions (from the plant tissues to the extraction media) and total phenol and anthocyanin contents.

Total phenol content (TPC): Ethanol, as organic solvent, could extract phenolic compounds more effective than that water could (23). Organic solvents, with relatively polar characteristics, are able to attract bioactive compounds and therefore their extraction are facilitated. In the present study, ethanol extracts showed significant differences with aqueous extracts $(P<0.05)$; similarly to those by Sarkar et al. (22). In the current study, the respective value $(209.68 \mathrm{mg} / \mathrm{L})$ achieved using ethanol extracts was significantly higher than that achieved using aqueous extracts. Hence, it was clear that ethanol could effectively extract compounds with less tendency to polar media and anthocyanins could efficiently be extracted with methanol other than ethanol (23).

Antioxidant activity: Black mulberry fruits are rich in anthocyanin and phenolic compounds. These compounds have been reported to include potential antioxidant activity due to their chemical structures. Plants and fruits produce these bioactive compounds to treat their disorders (24). They could be involved in antioxidant linked reactions. Higher DPPH showed that the aqueous-ethanol extract strongly acted as antioxidant. In fact, this was attributed to flavonoid, phenolic compound and anthocyanin content of the extract that could revive free radicals $(12,17,24)$. Moreover, antioxidant activity of the extracts was assessed using FRAP method based on ferric $\left(\mathrm{Fe}^{3+}\right)$ reduction. Therefore, antioxidant compounds could donate electrons to oxidized iron and thereby color changes indicated that how strongly the antioxidant constituents could exert their bioactive impacts. The $\mathrm{Fe}^{3+}$ ions were easily reduced by hydrogens within the phenolic groups; originated from strong antioxidant activity of the black mulberry extracts (23). Addition of ethanol resulted in further bioactive compound extractions and hence stronger reduction capacities for ethanol and aqueous-ethanol extracts (Table 2), compared to water extract. When ethanol was added to water, $\mathrm{IC}_{50}$ value decreased significantly. Therefore, ethanol could extract phenolic substances more efficiently than water.
Quantification of anthocyanins using highperformance liquid chromatography (HPLC): Anthocyanins were the major antioxidant compounds of the black mulberry extracts using HPLC. Cyanidin3-glucoside, cyanidin-3-rutinoside and cyanidin-3xyloside were reported as major anthocyanidin constituents in the black mulberry extracts. Similarly, Chen et al. (19) reported that cyanidin-3-glucoside was the major anthocyanin constituent in fresh and freeze-dried black mulberry extracts. It is verified that phenolic compounds can be affected by geographical locations and weather conditions. In addition, extraction conditions such as type of solvent, temperature and $\mathrm{pH}$ can change quantity and quality of anthocyanins $(19,25,14)$.

Heat treatment effects on chemical properties of the aqueous-ethanol extracts: Based on the findings of this study, the highest decrease in TPC was observed in extracts affected by indirect heat treatments at higher power and time. It was observed that prolonged and intensive process conditions resulted in lower TPC values; based on decomposition effects of the associated treatments. Thermal treatments, especially prolonged treatments, resulted in lower TPC values $(3,26,12)$. Non-thermal treatments were demonstrated to alter anthocyanin contents significantly at intensive and deteriorative conditions. Furthermore, it was clearly shown that use of higher temperatures, especially for longer times, resulted in decomposition of anthocyanins due to their susceptible structures to heat $(1,26,6,27)$. Flavonoids, phenolic compounds and anthocyanins are the major antioxidant constituents involved in electron donation. Therefore, microwaves at intensive powers could damage these bioactive and susceptible ingredients (10). In general, Microwave treatments $(900 \mathrm{~W}$ for 45 s) showed the most intensive adverse effects on antioxidant activity using DPPH and FRAP. Higher $\mathrm{IC}_{50}$ values indicated lower antioxidant activities while lower $\mathrm{IC}_{50}$ values indicated that lower concentrations of extracts were needed to scavenge $50 \%$ of the DPPH radicals. Therefore, $\gamma$-radiation at $10 \mathrm{KG}$ decomposed bioactive compounds and decreased antioxidant activities of the extracts. It could be concluded that intensive conditions resulted in lower antioxidant activities with higher $\mathrm{IC}_{50}$ values.

Heat treatment effects on anthocyanin contents of the aqueous-ethanol extracts: Of the current 
processes, thermal treatments at highlighted conditions intensively degraded the anthocyanin compounds. Based on the results of this study, cyanidin-3-glucoside, cyanidin-3-rutinoside and cyanidin-3-xyloside in the aqueous-ethanol black mulberry extracts decreased due to the thermal and non-thermal heat treatments. Thermal treatments can decompose anthocyanins that react to high temperature, oxidation and metal ion levels $(23,6,11,27)$. It can be suggested that simultaneous use of thermal and non-thermal treatments include more advantages than that use of these treatments alone does. Thermal treatments are usually used to inactivate enzymes (peroxidase and polyphenol oxidase), which are involved in quality changes of food ingredients. Fresh fruits and plants contain these enzymes in their tissues; hence, inactivation of the highlighted enzymes seems necessary. Heat treatments for enzymes inactivation have been shown to be more efficient than non-thermal treatments. Pretreatment can be carried out using thermal treatments and then pasteurization can be carried out using non-thermal processes to minimize the adverse effects of thermal processes $(28,10)$. In most studies, a combination of thermal and non-thermal processes is recommended due to less decomposition effects on anthocyanins and other susceptible bioactive compounds (27).

\section{Conclusion}

Colorful fruits, especially berries such as black mulberry, are rich in flavonoid, phenolic and anthocyanin compounds. The present study has revealed that use of mix solvents includes several advantages in terms of extraction efficacy. The aqueous-ethanol solvent more efficiently extracted phenolic compounds and anthocyanins; therefore, higher total contents of phenol and anthocyanin were achieved. In antioxidant activity, the aqueous-ethanol solvent showed higher RSA and ability to reduce ferric ions. Based on the results, both thermal and non-thermal processes showed less deteriorative effects at moderate conditions. Heat treatment at $70^{\circ} \mathrm{C}$ for $30 \mathrm{~s}$, microwave treatment at $600 \mathrm{~W}$ for $30 \mathrm{~s}$ and low-power $\gamma$-radiation $(5 \mathrm{KG})$ resulted in less degradations of anthocyanins.

\section{Financial disclosure}

The authors declared no financial interest.

\section{Funding/Support}

This research did not receive any specific grant from funding agencies in the public, commercial, or not-for-profit sectors.

\section{References}

1. Azofeifa G, Quesada S, Perez AM, Vaillant F, Michel A. Pasteurization of black mulberry juice preserves polyphenol-dependent inhibition for lipid peroxidation and intracellular radicals. Journal of Food Composition and Analysis. 2015; 42:56-62.

2. Wang WJ, Jung J, Tomasino E, YY Z. Optimization of solvent and ultrasound-assisted extraction for different anthocyanin rich fruit and their effects on anthocyanin compositions. LWT-Food Science and Technology. 2016; 72:229-38

3. Acosta-Montoya O, Vaillant F, Cozzano S, Mertz C, Perez AM, Castro MV. Phenolic content and antioxidant capacity of tropical highland blackberry (Rubus adenotrichus Schltdl.) during three edible maturity stages. Food Chemistry. 2010; 119(4):149701.

4. Wang WJ, Jung J, Tomasino E, Zhao YY. Optimization of solvent and ultrasound-assisted extraction for different anthocyanin rich fruit and their effects on anthocyanin compositions. LWT-Food Science and Technology. 2016; 72:229-38.

5. Jiao G. Extraction of anthocyanins from haskap berry pulp using supercritical carbon dioxide: Influence of cosolvent composition and pretreatment. LWT-Food Science and Technology. 2018; 98:237-44.

6. Lou HQ, Hu Y, Zhang LY, Sun P, Lu HF. Nondestructive evaluation of the changes of total flavonoid, total phenols, ABTS and DPPH radical scavenging activities, and sugars during mulberry (Morus alba L.) fruits development by chlorophyll fluorescence and RGB intensity values. LWT-Food Science and Technology. 2012; 47(1):19-24.

7. Blackhall ML, Berry R, Davies NW, Walls JT. Optimized extraction of anthocyanins from Reid Fruits' Prunus avium 'Lapins' cherries. Food Chemistry. 2018; 256:280-85.

8. Selvamuthukumaran, M Shi, J. Recent advances in extraction of antioxidants from plant by-products processing industries. Food Quality and Safety. 2017; $1(1): 61-81$.

9. Gomes WF, Tiwari BK, Rodriguez O, de Brito ES, Fernandes FAN, Rodrigues S S. Effect of ultrasound followed by high pressure processing on prebiotic cranberry juice. Food Chemistry. 2017; 218:261-68.

10. Rawson A, Patras A, Tiwari BK, Noci F, Koutchma TNB. Effect of thermal and non thermal processing technologies on the bioactive content of exotic fruits and their products: Review of recent advances. Food Research International. 2011; 44(7):1875-87. 
11. Vagiri M, Jensen M. Influence of juice processing factors on quality of black chokeberry pomace as a future resource for colour extraction. Food Chemistry. 2017;217:409-17.

12. Huang W-y, Zhang H-c, Liu W-x, Li C-y. Survey of antioxidant capacity and phenolic composition of blueberry, blackberry, and strawberry in Nanjing. Journal of Zhejiang University Science B. 2012;13 (2):94-102.

13. Van de Velde F, Grace MH, Esposito D, Pirovani MÉ, Lila MA. Quantitative comparison of phytochemical profile, antioxidant, and anti-inflammatory properties of blackberry fruits adapted to Argentina. Journal of Food Composition and Analysis. 2016; 47:82-91.

14. Yazdankhah S, Hojjati M, Azizi MH. The antidiabetic potential of black mulberry extract-enriched pasta through inhibition of enzymes and glycemic index. Plant Foods for Human Nutrition. 2019; 74 (1):149-55.

15. Cespedes CL, El-Hafidi M, Pavon N, Alarcon J. Antioxidant and cardioprotective activities of phenolic extracts from fruits of Chilean blackberry Aristotelia chilensis (Elaeocarpaceae), Maqui. Food Chemistry. 2008; 107(2):820-29.

16. Horwitz W, Latimer GW. Official Methods of Analysis of AOAC International Maryland. $18^{\text {th }}$ edn. Association of Official Analytical Chemists, Rockville, MD, USA. 2011.

17. Ozgen M, Serce S, Kaya C. Phytochemical and antioxidant properties of anthocyanin-rich Morus nigra and Morus rubra fruits. Scientia Horticulturae. 2019; 119(3):275-79.

18. Sariburun E, Şahin S, Demir C, Türkben C, Uylaşer V. Phenolic content and antioxidant activity of raspberry and blackberry cultivars. Journal of Food Science. 2010; 75(4):C328-C35.

19. Chen QQ, Li ZL, Bi JF, Zhou LY, Yi JY, Wu XY. Effect of hybrid drying methods on physicochemical, nutritional and antioxidant properties of dried black mulberry. LWT-Food Science and Technology. 2017; 80:178-84.

20. Benmeziane F, Cadot Y, Djamai R, Djermoun L. Determination of major anthocyanin pigments and flavonols in red grape skin of some table grape varieties (Vitis vinifera sp.) by high-performance liquid chromatography-photodiode array detection (HPLCDAD). OENO. 2016; 50(3):125-35.

21. Chirinos R, Rogez H, Campos D, Pedreschi R, Larondelle Y. Optimization of extraction conditions of antioxidant phenolic compounds from mashua (Tropaeolum tuberosum Ruiz \& Pavon) tubers. Separation and Purification Technology. 2017; 55(2):217-25.

22. Sarkar D, Orwat J, Hurburt T, Woods F, Pitts JA, Shetty K. Evaluation of phenolic bioactive-linked functionality of blackberry cultivars targeting dietary management of early stages type-2 diabetes using in vitro models. Scientia Horticulturae. 2016; 212:193202.

23. Castaneda-Ovando A, de Lourdes Pacheco-Hernandez M, Paez-Hernandez ME, Rodriguez JA, Galan-Vidal CA. Chemical studies of anthocyanins: A review. Food Chemistry. 2009; 113(4):859-71.

24. Shahidi F, Ambigaipalan P. Phenolics and polyphenolics in foods, beverages and spices: Antioxidant activity and health effects-A review. Journal of Functional Foods. 2015; 18:820-97.

25. Mokrani A, Madani K. Effect of solvent, time and temperature on the extraction of phenolic compounds and antioxidant capacity of peach (Prunus persica L.) fruit. Separation and Purification Technology. 2016;162:68-76.

26. Giampieri F, Tulipani S, Alvarez-Suarez JM, Quiles JL, Mezzetti B, Battino M. The strawberry: composition, nutritional quality, and impact on human health. Nutrition. 2012;28 (1):9-19.

27. Zhou M, Chen Q, Bi J, Wang Y, Wu X. Degradation kinetics of cyanidin 3-O-glucoside and cyanidin 3-Orutinoside during hot air and vacuum drying in mulberry (Morus alba L.) fruit: A comparative study based on solid food system. Food Chemistry. 2017; 229:574-79.

28. Etzbach L, Pfeiffer A, Schieber A, Weber F. Effects of thermal pasteurization and ultrasound treatment on the peroxidase activity, carotenoid composition, and physicochemical properties of goldenberry (Physalis peruviana L.) puree. LWT-Food Science and Technology. 2019; 100:69-74. 